\title{
Animal models for evaluation of albumin-based therapeutics
}

Jeannette Nilsen ${ }^{a, b}$, Inger Sandlie ${ }^{a, c}$, Derry C. Roopenian ${ }^{d}$ and Jan Terje Andersen ${ }^{a, b, c, e}$

${ }^{a}$ Centre for Immune Regulation (CIR) and Department of Immunology, Oslo University Hospital Rikshospitalet, Sognsvannsveien 20, 0372 Oslo, Norway. 'Institute of Clinical Medicine, University of Oslo, Klaus Torgårds vei 3, 0372 Oslo, Norway. 'Department of Biosciences, University of Oslo, Problemveien 7, 0315 Oslo, Norway. ${ }^{\mathrm{d}}$ The Jackson Laboratory, 600 Main St, Bar Harbor, ME 04609, USA. ${ }^{~}$ Department of Pharmacology, Oslo University Hospital Rikshospitalet, Sognsvannsveien 20, 0372 Oslo, Norway.

To whom correspondence should be addressed: Jan Terje Andersen, CIR and Department of Immunology, Oslo University Hospital Rikshospitalet and University of Oslo, PO Box 4956, Oslo N-0424, Norway. E-mail: j.t.andersen@medisin.uio.no. Telephone: 95159223.

\begin{abstract}
Albumin has a long serum half-life due to its unique ability to bind the cellular neonatal Fc receptor (FcRn), which provides protection from intracellular degradation. The interaction can be capitalized to improve the efficacy of drugs by extending their serum persistence. However, species-specific binding of albumin to FcRn challenges preclinical development. The goal of this brief review is to provide insights into how FcRn and cross-species binding differences affect the pharmacokinetics of human serum albumin (HSA) in different animal models, and gives an overview of genetically modified mice that may serve as improved models for testing of albumin-based drugs.
\end{abstract}

\section{Introduction}

Albumin is an abundant and long-lived protein in blood. In humans, it has a serum concentration of $40 \mathrm{mg} / \mathrm{ml}$ and a serum half-life of 3 weeks, which is only shared with IgG antibodies [1,2]. Albumin plays a key role in transportation of various small insoluble molecules, including fatty acids, hormones and chemical drugs $[3,4]$. Albumin has been further exploited to improve the serum half-life and efficacy of therapeutics, which are genetically fused, conjugated or associated via albumin-binding molecules. So far, this has led to the marketing of six drugs as well as several in pre-clinical and clinical development $[5,6]$.

While the extended half-life of albumin had been appreciated for decades [7], a mechanistic explanation only emerged much later. The key discovery was that both the serum concentration and half-life of albumin were substantially reduced in mice deficient for the neonatal Fc receptor ( $F c R n)$ in comparison to wild-type (WT) mice [8]. FcRn is a cellular receptor, comprised of a MHC class I family heavy chain (HC) FCGRT and a $\beta 2$-microglobulin $(\beta 2 \mathrm{~m})$ light chain (Fig. 1a), which was already known to bind and protect IgG antibodies from intracellular degradation [9-12]. This striking result opened new opportunities for the development of albumin-based therapeutics with tailored FcRn binding properties and further improved pharmacokinetics. However, cross-species differences in binding of albumin to FcRn limit the use of conventional animal models for preclinical evaluation. The 
goals of this brief review are to provide insights into how FcRn and cross-species binding differences affect the pharmacokinetics of human serum albumin (HSA) in different animal models.

\section{FcRn - a key controller of albumin homeostasis}

FcRn is expressed in multiple tissues and cell types across species [5,13]. A recent study demonstrated that FcRn in hepatocytes of the liver is important for maintaining the steadystate concentration of albumin in the blood, as the serum level was reduced to about $60 \%$ in mice with a liver lacking expression of the receptor [14]. Other reports have previously shown that FcRn-deficiency in renal tubular epithelial cells cause hypoalbuminea $[15,16]$. FcRn is present in hematopoietic and endothelial cells of most tissues $[13,17,18]$, and when expression was conditionally deleted in these cell types in mice, serum levels of both IgG and albumin were reduced, which supports the involvement of one or both in regulation of albumin homeostasis by recycling that prevents intracellular degradation [19]. A recent study demonstrated FcRn-dependent rescue of albumin from degradation in human endothelial cell lines [20]. In another study, human FcRn (hFcRn) over-expressed in polarized Madin-Darby canine kidney II epithelial cells was shown to mediate bidirectional transcytosis of HSA, as well as efficient recycling at the basal surface of the cells [14]. These studies support that albumin follows the same traffic pattern as IgG, which has been studied in detail (reviewed in [21,22]). IgG enters the endosomal pathway by fluid-phase pinocytosis, but instead of following the route to the lysosomes and degradation, it may be captured by FcRn and recycled to the cell membrane [23-26]. Moreover, FcRn interacts with albumin and IgG at distinct binding sites and in a similar $\mathrm{pH}$-dependent manner, with binding at acidic $\mathrm{pH}$ and not at neutral $\mathrm{pH}[8,27,28]$. The $\mathrm{pH}$-dependency is important for efficient FcRn-mediated recycling, as it promotes ligand binding in acidified endosomes and then release when exposed to neutral $\mathrm{pH}$ at the cell surface.

The interaction is characterized by conserved histidine residues in both FcRn and albumin, which are protonated and deprotonated in the $\mathrm{pH}$ 6.0-7.4 range. The $\mathrm{HC}$ of FcRn has three extracellular domains ( $\alpha 1, \alpha 2$ and $\alpha 3$ ), which is non-covalently associated with $\beta 2 \mathrm{~m}$ (Fig. 1a) $[29,30]$. At acidic $\mathrm{pH}, \mathrm{H} 166$ in the $\alpha 2$-domain of $\mathrm{hFcRn}$ forms intramolecular interactions that stabilize a loop in the $\alpha 1$-domain. This makes conserved tryptophan residues (W53 and W59) available for docking into hydrophobic pockets of albumin [28,31-34]. Albumin has three homologous domains, DI, DII, and DIII (Fig. 1b) [35]. Three conserved histidines (H464, $\mathrm{H} 510$ and $\mathrm{H} 535$ ) in DIII form both intra- and intermolecular interactions when protonated, which stabilizes a loop (residues 500-510) in an open orientation for W53 and W59 to be inserted [28,32,34]. Thus, DIII of HSA contains the main binding site for hFcRn and the interface is mainly hydrophobic. In addition, two surface-exposed loops in DI make direct electrostatic interactions with FcRn, which stabilize the interaction $[28,34,36]$.

\section{Targeting albumin for extended half-life}

Protein-based therapeutics may be genetically fused to the amino or carboxy terminal end of albumin (Fig. 2a). In one study, where a peptide or an antibody single-chain variable fragment was fused to either end of HSA via a glycine-serine linker, the N-terminal fusions had no or only minor negative effect on the FcRn interaction, whereas the C-terminal 
fusions decreased binding by up to 2-fold [37]. Another approach is chemical conjugation to albumin, either to surface-exposed amino acids or, in a site-specific manner, to a free cysteine (C34) in DI (Fig. 2b). Conjugation of polyethylene glycol polymers to C34 reduced FcRn binding affinity by 2-3 fold at acidic $\mathrm{pH}$, whereas attachment of an anticoagulant aptamer drug compromised the interaction by more than 9 -fold [38,39]. In comparison, conjugation of glucagon-like peptide-1 (GLP-1) resulted in a slight decrease in receptor binding [40]. Thus, both the nature of the fused or conjugated drug and the choice of linker or conjugation chemistry may affect FcRn binding. Even a small reduction in receptor binding may have a negative effect on in vivo half-life, as the albumin-fused or conjugated drug compete with large amounts of endogenous albumin for binding to the FcRn.

Engineering of HSA for improved FcRn binding is an attractive strategy for long lived albumin-based therapeutic design (Fig. 2c). We have previously demonstrated that substitution of a lysine in position $\mathbf{5 7 3}$ of the C-terminal end of HSA, to any of the other 19 amino acids, improves binding to $\mathrm{hFcRn}$ at $\mathrm{pH} 6.0$, with no or minor effect on binding at $\mathrm{pH}$ 7.4 [41]. Mutation to a proline (K573P) gave rise to 12-fold stronger binding affinity, without a concomitant increase in binding at neutral $\mathrm{pH}$ [41]. While conjugation of polyethylene glycol or an anticoagulant aptamer to C34 resulted in decreased FcRn binding, the K573P engineered HSA-conjugates bound more strongly than unconjugated WT HSA, supporting that the single-point mutation may be used to compensate for the decrease in binding caused by a conjugated drug [38,39]. Furthermore, another study used yeast display to identify single amino acid substitutions that increased the binding strength to hFcRn, such as the V547A mutation in HSA5 that gave rise to 3.2-fold improved binding [34]. Moreover, HSA7 with two mutations combined, V547A and E505G, bound with at least 40-fold stronger affinity at $\mathrm{pH}$ 6.0. However, a concomitant increase in binding at neutral $\mathrm{pH}$ was measured for both variants, and HSA7 bound 5-fold more strongly than HSA5 [34].

Therapeutics may also be fused or conjugated to albumin-binding molecules that associate with endogenous albumin after administration (Fig. 2d). Examples of such molecules are albumin-binding domain [42,43], albumin-binding lipids and peptides [6,44], albuminbinding designed ankyrin repeat proteins (DARPin) [45] and different forms of antibodyderived fragments with specificity for albumin [46-49]. To obtain extended half-life using this strategy, it is important that binding to albumin does not interfere with the FcRnalbumin interaction and binding needs to be retained at neutral $\mathrm{pH}$ as well as at lower $\mathrm{pH}$ encountered in the endosomes.

\section{Conventional animal models}

Rodents, rabbits and non-human primates are frequently used animal models for preclinical evaluation of drugs. However, choosing an animal model best suited for evaluation of HSAbased drugs is not necessarily straightforward. The reason is the differences in HSA binding to FcRn that exist across species despite high sequence conservation of both proteins. Importantly, FcRn from rodents binds HSA poorly in comparison to rodent albumin, e.g. mouse FcRn ( $\mathrm{mFcRn}$ ) binds mouse serum albumin (MSA) 25-fold more strongly than HSA $[37,41,50]$. In combination with high levels of endogenous albumin, injected HSA encounters strong competition in binding to FcRn. In mice, the consequence of this was demonstrated when WT HSA showed close to the same half-life as a HSA mutant (K500A) 
with very weak binding affinity for FcRn (Table 1) [40,41]. The half-life of HSA in WT mice and in FcRn-deficient mice was also close to identical [51]. In rats, the half-life of HSA was found to be only $15 \mathrm{~h}$ compared to $49 \mathrm{~h}$ for rat albumin [52]. Similarly, the reported half-life for HSA in rabbits is less than half of that measured for rabbit albumin [53,54]. On the other hand, FcRn from rhesus and cynomolgus monkeys binds only slightly more weakly to HSA than to albumin from the same species [37,41], and half-lives of $131 \mathrm{~h}$ and $169 \mathrm{~h}$ has been measured for HSA in cynomolgus monkeys compared to $144 \mathrm{~h}$ reported for cynomolgus monkey albumin $[2,34,41]$. An overview of albumin half-lives in the different animal models is given in table 1.

While non-human primates are good surrogate models, ethical reasons and high cost limit their use for evaluation, and therefore, mice are the preferred choice for early-stage drug development. Ease of handling and the numerous models with modified genetics further speak in favor of mice.

\section{Conventional mice}

The use of conventional mice may be considered for engineered HSA variants that have gained binding affinity for $\mathrm{mFcRn}$ due to introduced mutations, and may in some cases be the only choice for efficacy testing in disease mouse models. For instance, the K573P mutation that improves binding to hFcRn when introduced in HSA, also increased binding to $\mathrm{mFcRn}$ by 15 -fold [41]. MSA has a proline in this position, which therefore partly explains why MSA binds more strongly to $\mathrm{mFcRn}$ than HSA. The mutation gave rise to 1.5 -fold extended half-life in WT mice, supporting that HSA-K573P has increased ability to compete with endogenous MSA for receptor binding [41]. Moreover, HSA5 behaved similarly to WT HSA, while more than 2-fold longer serum half-life was measured for HSA7 [34]. However, the results did not correspond to that observed in hFcRn transgenic mice and monkeys, as described below. Thus, pharmacokinetic evaluation in mice requires careful interpretation, as mutations in HSA may affect the interaction to the mouse and human receptors differently.

Albumin-binding molecules and attached drugs may be evaluated in WT mice if they bind to MSA. For instance, ribosome display was used to select albumin-binding DARPin molecules that bound albumin of different species with $\mathrm{nM}$ affinities at both $\mathrm{pH} 6.0$ and $\mathrm{pH} 7.4$ [45]. When an albumin-binding DARPin was fused to a DARPin with no specificity, the fusion exhibited a half-life of 44 hours in WT mice, which is similar to that reported for MSA (Table 1), while a non-albumin binding DARPin was eliminated in minutes [45].

\section{Human FcRn transgenic mice}

Humanized mice that express $\mathrm{hFcRn}$ instead of the mouse receptor have been developed (Fig. 3). Tg276 and Tg32 are two genetically modified C57BL/6J strains that lack intact genes for $\mathrm{mFcRn}$, and are transgenic for the $\mathrm{HC}$ of $\mathrm{hFcRn}[8,12]$. Both strains express the human $\mathrm{HC}$, which then pair with mouse $\beta 2 \mathrm{~m}(\mathrm{~m} \beta 2 \mathrm{~m})$. The Tg276 mice carry human FCGRT CDNA, which is ubiquitously expressed under the control of a human cytomegalovirus immediate early promoter/enhancer chicken beta-actin/rabbit beta-globin hybrid (CAG) promoter, whereas the Tg32 mice carry the complete human FCGRT gene, including the human FCGRT 
regulatory elements. Tg32 mice that co-express human $\beta 2 \mathrm{~m}(\mathrm{~h} \beta 2 \mathrm{~m})$ have also been made [55]. MSA concentrations of $25 \mathrm{mg} / \mathrm{ml}$ and $29 \mathrm{mg} / \mathrm{ml}$ have been measured in Tg276 and Tg32 mice, respectively, which is in the range of that measured in WT mice [56].

Such transgenic mice are frequently used to study the pharmacokinetics of human IgG antibodies and Fc-based therapeutics $[55,57,58]$. Notably, hFcRn binds weakly to mouse IgG and the level of endogenous IgG is therefore lower than normal. The hFcRn transgenic strains are also available on immunodeficient background, and can therefore be used in xenograft studies for efficacy testing of anti-tumor compounds [58].

HSA binds more strongly to hFcRn than to mFcRn $[37,41,50]$. In Tg32 mice, WT HSA showed 2-times the half-life measured for a variant with weak affinity for hFcRn (HSA-K500A) [41], which supports that HSA is recycled by the human receptor in the mouse model (Table 1). Importantly, hFcRn, with human $\mathrm{HC}$ and $\mathrm{h} \beta 2 \mathrm{~m}$, has 5-fold stronger binding affinity for MSA than for HSA [50,59], and pharmacokinetic evaluation of HSA-based compounds in the Tg32 mice has been questioned. Curiously, a recent report revealed that MSA and HSA bind with similar binding affinity to a chimeric receptor consisting of the human $\mathrm{HC}$ paired with $\mathrm{m} \beta_{2} \mathrm{~m}$, which is expressed by these mice [59].

In regard to evaluation of engineered variants, HSA-K573P showed 2-fold stronger binding to $\mathrm{hFcRn}$ than MSA, which translated into 1.4-fold prolonged half-life compared to WT HSA in Tg32 mice (Table 1) [41]. As a proof-of-concept, HSA-K573P was also tested in cynomolgus monkeys. The improvement in binding to cynomolgus monkey FcRn was similar to that observed towards hFcRn, and HSA-K573P bound 11-fold more strongly than cynomolgus monkey albumin. The half-life was extended by 1.6-fold, from 5.4 to 8.8 days, which supports that the Tg32 mice may be used to predict in vivo behavior in monkeys [41]. The half-life of HSA5 and HSA7 was determined in Tg276 mice, and both showed about 1.5fold longer half-life than WT HSA [34]. HSA7 bound more strongly than HSA5 to hFcRn at both $\mathrm{pH} 6.0$ and $\mathrm{pH} 7.4$, and the increased binding at $\mathrm{pH} 7.4$ may explain why HSA7 did not exhibit a longer half-life than HSA5. When tested in cynomolgus monkeys, the half-life of HSA7 was 1.3-1.6 times the half-life of WT HSA, which corresponds to the relative difference measured in the humanized mice [34].

\section{Human FcRn transgenic and albumin deficient mice}

Tg32 mice have been further engineered to lack expression of endogenous albumin (Tg32$\mathrm{Alb}^{-/-}$) (Fig. 3c) [51]. The strain was created by targeting the Alb gene by transcription activator-like effector nucleases, which resulted in a 2 bp deletion in exon 4 . This in turn caused a frame shift and a premature stop codon. The mice are analbuminemic, but the total protein level in the blood is only slightly lower than normal, as the lack of albumin is compensated by increased expression of other serum proteins. Strikingly, the serum half-life of HSA was measured to be 24.1 days after intravenous administration, which is close to that measured in humans and 4-fold longer than in the hFcRn transgenic Tg32 strain (Table 1). Thus, the presence of hFcRn and absence of competing endogenous MSA resulted in efficient protection of WT HSA from intracellular degradation [51].

The strain allows studies of how hFcRn binding kinetics of engineered HSA variants as well as fusions and conjugates directly influence the half-life in the absence of competition. $A$ 
further advantage is that such studies may be extended to address how competition affects the pharmacokinetics, by administration of titrated amounts of WT HSA prior to the test compound. In a recent study, $\mathrm{Tg} 32-\mathrm{Alb}^{-/}$mice were preloaded with $500 \mathrm{mg} / \mathrm{kg} \mathrm{HSA}$ and high serum levels were maintained for more than a week in control mice that were given PBS, but not in mice that received a monoclonal antibody with specificity for the albumin-binding site on hFcRn [14]. Thus, the mice tolerated exposure to high doses of HSA, and again, the serum level of HSA in this strain was fully dependent on hFcRn.

\section{Human FcRn and HSA transgenic mice}

Humanized double transgenic mice (C57BL/6J), having the genes encoding $\mathrm{mFcRn}$ and MSA replaced by their human counterparts, have recently been reported (Fig. 3d) [59]. Specifically, the hFcRn HC cDNA was inserted in-frame with the murine ATG in exon 2 of the gene encoding $\mathrm{mFcRn}$, whereas cDNA encoding the MSA signal peptide followed by the coding sequence for HSA was inserted in-frame with the murine ATG in exon 1 of the MSA gene. Thus, the expression levels of both hFcRn and HSA are under the control of the endogenous mouse promoters. In the case of the receptor, it is likely to parallel the endogenous distribution pattern of $\mathrm{mFcRn}$. As in the other transgenic mice, the receptor is chimeric, in that the human $\mathrm{HC}$ pairs with $\mathrm{m} \beta 2 \mathrm{~m}$.

The double transgenic mice have a serum HSA concentration of $17 \mathrm{mg} / \mathrm{ml}$, whereas the levels of another 30 serum components were comparable to that in WT mice. HSA expressed by the mice was shown to bind soluble hFcRn with a binding affinity similar to that measured for recombinant and human serum-derived albumin, and HSA from all three sources bound equally well to $h F c R n$, whether the $H C$ was paired with $h \beta 2 m$ or $m \beta 2 m$.

The pharmacokinetics of WT HSA and two engineered variants, K573P and K500A, have been compared, and found to be 57 hours for WT, only half of that for K500A, and roughly 80 hours for K573P (Table 1). Thus, the half-lives measured for the three variants were close to that previously determined in the presence of endogenous MSA in Tg32 mice, and the relative differences to WT HSA were the same [41].

Lastly, the double transgenic mouse may prove to be a more suitable model for evaluation of drugs attached to albumin-binding molecules that show low cross-species reactivity, and of small drugs that binds reversibly to pockets of endogenous albumin, as species differences in the binding pockets can affect the on- and off-kinetics [4].

\section{Concluding remarks}

The pharmacokinetics of drugs may be improved by attachment to albumin, and exploitation of the FcRn-albumin interaction is attracting increasing interest, as it provides opportunities for rational design of HSA that tailor FcRn binding properties to control serum half-lives. Importantly, cross-species FcRn binding differences must be taken into consideration prior to in vivo testing of new drug candidates in animal models. Currently, $\operatorname{Tg} 32$ and $\operatorname{Tg} 276$ transgenic mice are the state-of-the-art preclinical models for evaluation of therapeutic human IgG antibodies. The relevance of these models for testing of HSA variants and HSA-attached drugs has been questioned, however, as MSA binds hFcRn more strongly than HSA. This has motivated the generation of novel mouse strains that have the 
gene encoding MSA silenced and/or replaced with the gene encoding HSA, while also being $\mathrm{hFcRn}$ transgenic. Each of these mice expresses a chimeric FcRn heterodimer, with the $\mathrm{hFcRn} \mathrm{HC}$ pairing with $\mathrm{m} \beta 2 \mathrm{~m}$. The chimeric receptor was recently found to bind MSA and HSA with very similar binding affinity. Thus, the presence of endogenous MSA in Tg32 and Tg276 mice does not necessarily limit their use for evaluating HSA-based therapeutics. Nevertheless, whether the presence of $m \beta 2 m$, rather than $h \beta 2 m$, affects the pharmacokinetic evaluation of HSA should be investigated.

There is also a major interest in optimization of therapeutic human IgG and Fc-based therapeutics by modifying their interaction with $\mathrm{FcRn}$, and one may want to compare the performance of such drugs with HSA-based therapeutics in mice. In this regard, it is of relevance that MSA binds hFcRn strongly while mouse IgG binds poorly, and as such, the competition from endogenous IgG and MSA for receptor binding differs considerably in hFcRn transgenic mice. In Tg32-Alb ${ }^{-/}$mice on the other hand, the combination of low IgG levels and no albumin allows physiologically relevant levels of both to be achieved by injection of human ligands prior to drug evaluation.

\section{FOOTNOTES}

Acknowledgements: This work was supported in part by the Research Council of Norway through its Centre of Excellence funding scheme (project 179573), and J.TA and J.N were supported by the Research Council of Norway (grants 230526/F20 and 179573/V40).

Declarations of interest: Roopenian has patents and shares licensing revenues on some of the mice described. Sandlie and Andersen are inventors on patents that describe albumin variants filed by Novozymes A/S. Sandlie consults for Albumedix A/S, which commercializes the Veltis ${ }^{\circledR}$ technology. 
Table 1. $\beta$-phase half-life of albumin in animal models

\begin{tabular}{|c|c|c|c|c|c|c|c|}
\hline Animal & Albumin & $T_{1 / 2 \beta}(h)$ & Ref. & Animal & HSA variant & $T_{1 / 2 \beta}(h)$ & Ref. \\
\hline \multirow[t]{2}{*}{ Human } & Human (pd) & 450 & {$[2]$} & Mouse & K500A (r) & 19.1 & [41] \\
\hline & & & & & K573P (r) & 30.6 & [41] \\
\hline \multirow[t]{2}{*}{ Monkey } & Monkey (pd) & 144 & {$[2]$} & & V547A (r) & 33.0 & [34] \\
\hline & & & & & V547A/E505G(r) & 67.5 & [34] \\
\hline \multirow[t]{2}{*}{ Rabbit } & Rabbit (pd) & $112.8 \pm 8.6$ & [54] & $\operatorname{Tg} 32$ & WT (pd) & $139.2 \pm 12$ & [51] \\
\hline & Rabbit (r) & $103.7 \pm 6.0$ & [54] & $\mathrm{mFCRn}^{-1}$ & WT $(r)$ & 67.0 & [41] \\
\hline \multirow[t]{2}{*}{ Rat } & Rat (pd) & 53.0 & [47] & & $\mathrm{K} 500 \mathrm{~A}(\mathrm{r})$ & 31.3 & [41] \\
\hline & Rat (pd) & 49.1 & {$[52]$} & & $\mathrm{K} 573 \mathrm{P}(\mathrm{r})$ & 95.2 & [41] \\
\hline \multirow[t]{3}{*}{ Mouse } & Mouse (pd) & $35.0 \pm 3.0$ & [8] & $\operatorname{Tg} 267$ & WT $(r)$ & 30.3 & [34] \\
\hline & Mouse (pd) & $39.0 \pm 1.0$ & [8] & $\mathrm{mFCRn}^{-1}$, & V547A (r) & 46.2 & [34] \\
\hline & & & & & V547A/E505G(r) & 44.9 & [34] \\
\hline \multirow[t]{2}{*}{ Monkey } & Human (r) & 131.7 & {$[41]$} & Tg32-Alb & WT (pd) & $578.4 \pm 67$ & [51] \\
\hline & Human (r) & 169 & [34] & $\begin{array}{l}\mathrm{mFCRn}^{-/}, \mathrm{MSA}^{-\%} \\
\mathrm{hFcRn}^{+/+}\end{array}$ & & & \\
\hline Rabbit & Human (r) & $47.0 \pm 6.0$ & {$[53]$} & Albumus & WT (r) & $57 \pm 13$ & [59] \\
\hline \multirow[t]{2}{*}{ Rat } & Human (pd) & 14.8 & {$[52]$} & $\begin{array}{l}\mathrm{mFCRn}^{-1}, \mathrm{MSA}^{-\%} \\
\mathrm{hFCRn}^{+/+} \mathrm{HSA}^{+/+}\end{array}$ & K500A (r) & $29 \pm 3$ & \\
\hline & & & & 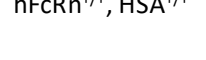 & $\mathrm{K} 573 \mathrm{P}(\mathrm{r})$ & $80 \pm 18$ & \\
\hline \multirow[t]{3}{*}{ Mouse } & Human (pd) & $62.4 \pm 2.4$ & {$[51]$} & Monkey & $\mathrm{K} 573 \mathrm{P}(\mathrm{r})$ & 210.7 & [41] \\
\hline & Human (r) & 21.0 & {$[41]$} & & V547A/E505G(r) & 259 & [34] \\
\hline & Human (r) & 29.9 & [34] & & & & \\
\hline
\end{tabular}

Abbreviations used in the table: pd, plasma-derived; $r$, recombinant produced; Ref., reference; $T_{1 / 2 \beta}(h), \beta$-phase half-life given in hours. 
Table 2. Abbreviations

\begin{tabular}{|ll|}
\hline WT & wild-type \\
GLP-1 & Glucagon-like peptide-1 \\
FcRn & neonatal Fc receptor \\
hFcRn & human FcRn \\
mFcRn & mouse FcRn \\
HC & heavy chain \\
$\beta 2 m$ & B2-microglobulin \\
h $\beta 2 m$ & human $\beta 2 m$ \\
m $32 m$ & mouse $\beta 2 m$ \\
HSA & human serum albumin \\
MSA & mouse serum albumin \\
DI & Domain I \\
DII & Domain II \\
DIII & Domain III \\
DARPin & designed ankyrin repeat proteins \\
CAG & human cytomegalovirus immediate \\
& early promoter/enhancer chicken \\
& beta-actin/rabbit \\
& hybrid promoter. \\
& \\
\end{tabular}




\section{FIGURES}

a

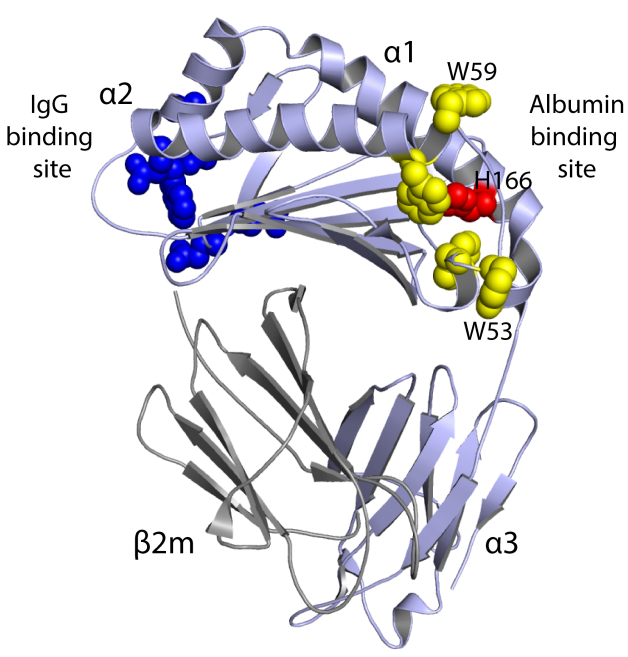

b

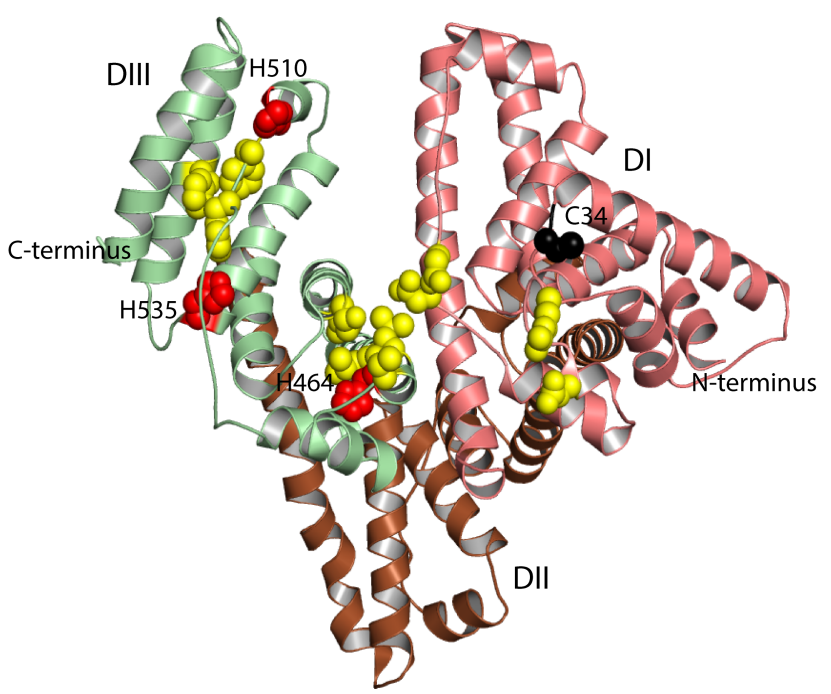

Figure 1. Crystal structures of hFcRn and HSA. $a$. A crystal structure of recombinant soluble $\mathrm{hFcRn} \mathrm{HC}(\alpha 1, \alpha 2$ and $\alpha 3)$ in blue and the $\beta 2 \mathrm{~m}$ subunit in grey [30]. Residues in the IgGbinding site are shown in dark blue. $\mathrm{H} 166$ that govern $\mathrm{pH}$-dependent binding of albumin is shown in red, whereas other important residues (W51, W53, W59 and W61) in the albuminbinding site are shown in yellow. $b$. A crystal structure of HSA with its three domains, DI, DII and DIII, in salmon pink, brown and green, respectively [35]. The C- and N-terminal ends are indicated and $\mathrm{C} 34$ is shown in black. Residues that govern pH-dependent binding ( $\mathrm{H} 464$, $\mathrm{H} 510$ and H535) are shown in red, whereas residues in the FcRn binding pockets of DIII and in the FcRn binding loops of $\mathrm{DI}$ are shown in yellow. The figures were made using PyMOL and the crystal structure data of hFcRn (PDB 3M1B) and HSA (PDB 1AO6).
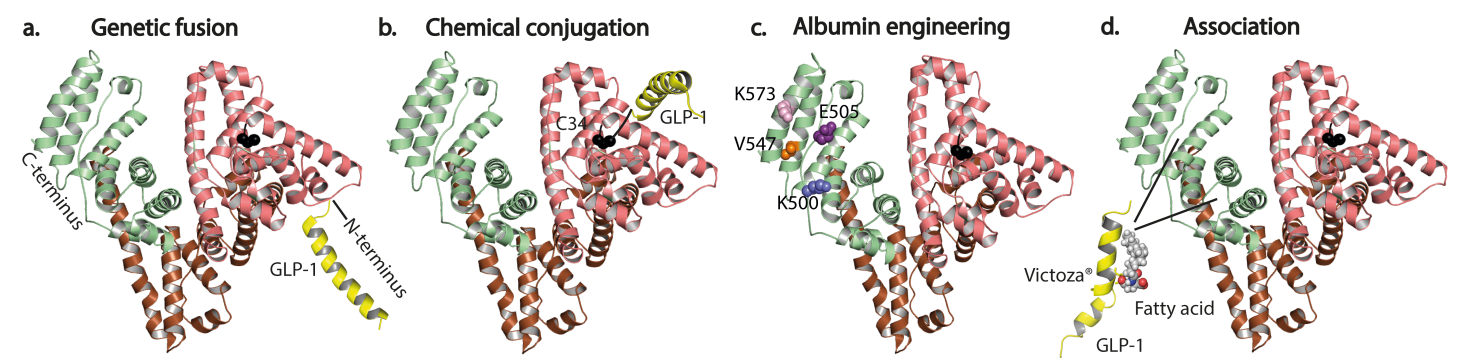

Figure 2. Albumin-based strategies to improve serum half-life of drugs. Illustrations of a crystal structure of HSA, where DI, DII and DIII are shown in salmon pink, brown and green, respectively. $a$. Genetic fusion of a drug to the C- or N-terminal end of HSA. $b$. Chemical conjugation of a drug to HSA via C34 (shown in black). c. Use of engineered HSA variants. Examples of residues that have been substituted in reported HSA variants are shown; K500 (blue), E505 (purple), V547 (orange) and K573 (pink). $d$. Conjugation or fusion of a drug to albumin-binding molecules. The figures were made using PyMOL with the following PDB data: HSA (1AO6), Victoza ${ }^{\circledR} /$ Liraglutide ${ }^{\circledR}$ (4APD) and GLP-1 (31OL). 


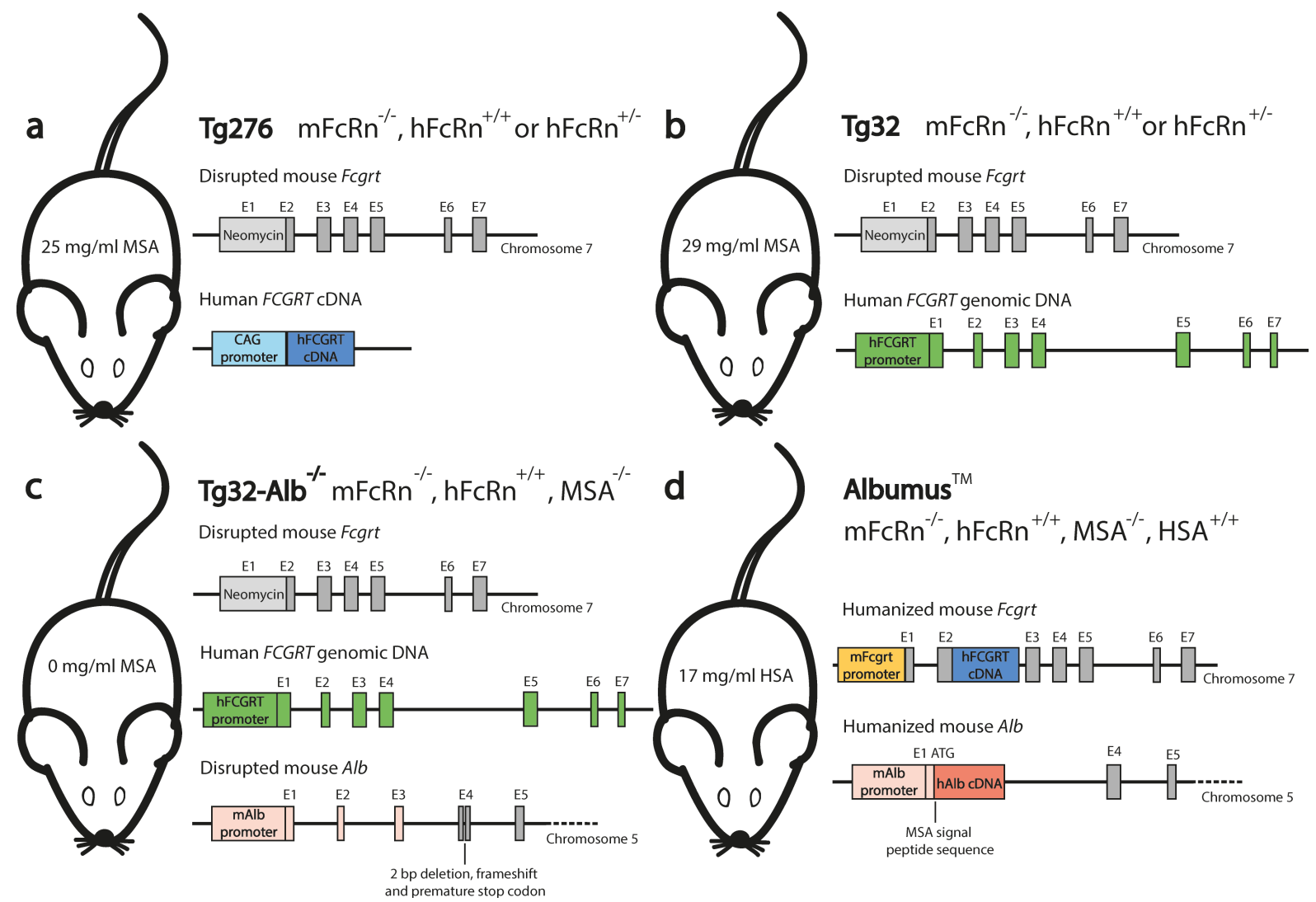

Figure 3. Humanized mouse models for evaluation of albumin-based drugs. The mice have disrupted genes for the $\mathrm{HC}$ of $\mathrm{mFcRn}$ as shown in gray, but express $\mathrm{m} \beta 2 \mathrm{~m}$ (not shown). The serum level of albumin expressed by each strain is shown inside the mouse illustrations $[51,56,59]$. $a$, Tg276 mice express the human FCGRT cDNA transgene (dark blue) under the control of the ubiquitous CAG promoter (light blue) [8]. $b-c, \operatorname{Tg} 32$ mice express a transgene containing the genomic DNA of human FCGRT under the control of the human promoter as shown in green [12]. c, Tg32-Alb $\%$ mice lack 2 bp in exon 4 of the MSA gene in addition, which results in a premature stop codon as indicated [51]. $d$, Albumus ${ }^{\mathrm{TM}}$ mice express human FCGRT cDNA (dark blue) under the control of the mouse Fcgrt promoter (orange). In addition, the mice express chimeric Alb cDNA, encoding the signal peptide sequence of MSA and the amino acid sequence of mature HSA (dark red), which is regulated by the mouse $A / b$ promoter (light red) [59]. 


\section{REFERENCES}

1. Waldmann TA, Strober W: Metabolism of immunoglobulins. Prog Allergy 1969, 13:1-110.

2. Peters T, Jr.: Serum albumin. Adv Protein Chem 1985, 37:161-245.

3. Fasano M, Curry S, Terreno E, Galliano M, Fanali G, Narciso P, Notari S, Ascenzi P: The extraordinary ligand binding properties of human serum albumin. IUBMB Life 2005, 57:787-796.

4. Day YS, Myszka DG: Characterizing a drug's primary binding site on albumin. J Pharm Sci 2003, 92:333-343.

5. Bern M, Sand KM, Nilsen J, Sandlie I, Andersen JT: The role of albumin receptors in regulation of albumin homeostasis: Implications for drug delivery. J Control Release 2015, 211:144-162.

6. Elsadek B, Kratz F: Impact of albumin on drug delivery--new applications on the horizon. J Control Release 2012, 157:4-28.

7. Sterling K: The Turnover Rate of Serum Albumin in Man as Measured by I-131-Tagged Albumin. J. Clin. Invest. 1951, 30:1228-1237.

8. Chaudhury C, Mehnaz S, Robinson JM, Hayton WL, Pearl DK, Roopenian DC, Anderson CL: The major histocompatibility complex-related Fc receptor for IgG (FcRn) binds albumin and prolongs its lifespan. J Exp Med 2003, 197:315-322.

9. Ghetie V, Hubbard JG, Kim JK, Tsen MF, Lee Y, Ward ES: Abnormally short serum halflives of IgG in beta 2-microglobulin-deficient mice. Eur. J. Immunol. 1996, 26:690-696. 10. Israel EJ, Wilsker DF, Hayes KC, Schoenfeld D, Simister NE: Increased clearance of IgG in mice that lack beta(2)-microglobulin: Possible protective role of FcRn. Immunology 1996, 89:573-578.

11. Junghans RP, Anderson CL: The protection receptor for IgG catabolism is the beta(2)microglobulin-containing neonatal intestinal transport receptor. Proc Natl Acad Sci U S A 1996, 93:5512-5516.

12. Roopenian DC, Christianson GJ, Sproule TJ, Brown AC, Akilesh S, Jung N, Petkova S, Avanessian L, Choi EY, Shaffer DJ, et al.: The MHC class I-like IgG receptor controls perinatal IgG transport, IgG homeostasis, and fate of IgG-Fc-coupled drugs. J. Immunol. 2003, 170:3528-3533.

13. Latvala S, Jacobsen B, Otteneder MB, Herrmann A, Kronenberg S: Distribution of FcRn Across Species and Tissues. J Histochem Cytochem 2017, 65:321-333.

14. Pyzik M, Rath T, Kuo TT, Win S, Baker K, Hubbard JJ, Grenha R, Gandhi A, Kramer TD, Mezo AR, et al.: Hepatic FcRn regulates albumin homeostasis and susceptibility to liver injury. Proc Natl Acad Sci U S A 2017, 114:E2862-E2871.

15. Tenten V, Menzel S, Kunter U, Sicking EM, van Roeyen CRC, Sanden SK, Kaldenbach M, Boor P, Fuss A, Uhlig S, et al.: Albumin Is Recycled from the Primary Urine by Tubular Transcytosis. J Am Soc Nephrol 2013, 24:1966-1980.

16. Sarav M, Wang Y, Hack BK, Chang A, Jensen M, Bao LH, Quigg RJ: Renal FcRn Reclaims Albumin but Facilitates Elimination of IgG. J Am Soc Nephrol 2009, 20:1941-1952.

17. Borvak J, Richardson J, Medesan C, Antohe F, Radu C, Simionescu M, Ghetie V, Ward ES: Functional expression of the MHC class I-related receptor, FcRn, in endothelial cells of mice. Int Immunol 1998, 10:1289-1298.

18. Zhu X, Meng M, Dickinson BL, Li X, Mizoguchi E, Miao L, Wang Y, Robert C, Claypool SM, $\mathrm{Wu} B$, et al.: MHC class I-related neonatal Fc receptor for IgG is functionally expressed in monocytes, macrophages and dendritic cells. FASEB J. 2001, 15:A1034-A1034. 
19. Montoyo HP, Vaccaro C, Hafner M, Ober RJ, Mueller W, Ward ES: Conditional deletion of the MHC class I-related receptor FcRn reveals the sites of IgG homeostasis in mice. Proc Natl Acad Sci U S A 2009, 106:2788-2793.

20. Schmidt EGW, Hvam ML, Antunes F, Cameron J, Viuff D, Andersen B, Kristensen NN, Howard KA: Direct demonstration of a neonatal Fc receptor (FcRn)-driven endosomal sorting pathway for cellular recycling of albumin. J Biol Chem 2017, 292:13312-13322. 21. Ward ES, Devanaboyina SC, Ober RJ: Targeting FcRn for the modulation of antibody dynamics. Mol. Immunol. 2015, 67:131-141.

22. Ward ES, Ober RJ: Chapter 4: Multitasking by exploitation of intracellular transport functions the many faces of FcRn. Adv. Immunol. 2009, 103:77-115.

23. Ober RJ, Martinez C, Lai X, Zhou J, Ward ES: Exocytosis of IgG as mediated by the receptor, FcRn: an analysis at the single-molecule level. Proc Natl Acad Sci U S A 2004, 101:11076-11081.

24. Ober RJ, Martinez C, Vaccaro C, Zhou J, Ward ES: Visualizing the site and dynamics of IgG salvage by the MHC class I-related receptor, FcRn. J. Immunol. 2004, 172:2021-2029. 25. Prabhat P, Gan Z, Chao J, Ram S, Vaccaro C, Gibbons S, Ober RJ, Ward ES: Elucidation of intracellular recycling pathways leading to exocytosis of the Fc receptor, FcRn, by using multifocal plane microscopy. Proc Natl Acad Sci U S A 2007, 104:5889-5894.

26. Ward ES, Martinez C, Vaccaro C, Zhou J, Tang Q, Ober RJ: From sorting endosomes to exocytosis: association of Rab4 and Rab11 GTPases with the Fc receptor, FcRn, during recycling. Mol Biol Cell 2005, 16:2028-2038.

27. Chaudhury C, Brooks CL, Carter DC, Robinson JM, Anderson CL: Albumin binding to FcRn: distinct from the FcRn-IgG interaction. Biochemistry 2006, 45:4983-4990.

28. Oganesyan V, Damschroder MM, Cook KE, Li Q, Gao CS, Wu HR, Dall'Acqua WF:

Structural Insights into Neonatal Fc Receptor-based Recycling Mechanisms. J. Biol. Chem. 2014, 289:7812-7824.

29. Burmeister WP, Gastinel LN, Simister NE, Blum ML, Bjorkman PJ: Crystal structure at $\mathbf{2 . 2}$ A resolution of the MHC-related neonatal Fc receptor. Nature 1994, 372:336-343. 30. Mezo AR, Sridhar V, Badger J, Sakorafas P, Nienaber V: X-ray Crystal Structures of Monomeric and Dimeric Peptide Inhibitors in Complex with the Human Neonatal Fc Receptor, FcRn. J. Biol. Chem. 2010, 285:27694-27701.

31. Andersen JT, Dee Qian J, Sandlie I: The conserved histidine $\mathbf{1 6 6}$ residue of the human neonatal Fc receptor heavy chain is critical for the $\mathrm{pH}$-dependent binding to albumin. Eur. J. Immunol. 2006, 36:3044-3051.

32. Andersen JT, Dalhus B, Cameron J, Daba MB, Plumridge A, Evans L, Brennan SO, Gunnarsen KS, Bjoras M, Sleep D, et al.: Structure-based mutagenesis reveals the albuminbinding site of the neonatal Fc receptor. Nat Commun 2012, 3:610.

33. Sand KM, Dalhus B, Christianson GJ, Bern M, Foss S, Cameron J, Sleep D, Bjoras M, Roopenian DC, Sandlie I, et al.: Dissection of the neonatal Fc receptor (FCRn)-albumin interface using mutagenesis and anti-FcRn albumin-blocking antibodies. J Biol Chem 2014, 289:17228-17239.

34. Schmidt MM, Townson SA, Andreucci AJ, King BM, Schirmer EB, Murillo AJ, Dombrowski C, Tisdale AW, Lowden PA, Masci AL, et al.: Crystal Structure of an HSA/FcRn Complex Reveals Recycling by Competitive Mimicry of HSA Ligands at a pH-Dependent Hydrophobic Interface. Structure 2013, 21:1966-1978.

35. Sugio S, Kashima A, Mochizuki S, Noda M, Kobayashi K: Crystal structure of human serum albumin at 2.5 A resolution. Protein Eng 1999, 12:439-446. 
36. Sand KM, Bern M, Nilsen J, Dalhus B, Gunnarsen KS, Cameron J, Grevys A, Bunting K, Sandlie I, Andersen JT: Interaction with both domain I and III of albumin is required for optimal pH-dependent binding to the neonatal Fc receptor (FcRn). J Biol Chem 2014, 289:34583-34594.

37. Andersen JT, Cameron J, Plumridge A, Evans L, Sleep D, Sandlie I: Single-chain variable fragment albumin fusions bind the neonatal Fc receptor ( $F C R n)$ in a species-dependent manner: implications for in vivo half-life evaluation of albumin fusion therapeutics. $J$ Biol Chem 2013, 288:24277-24285.

38. Petersen SS, Klaning E, Ebbesen MF, Andersen B, Cameron J, Sorensen ES, Howard KA: Neonatal Fc Receptor Binding Tolerance toward the Covalent Conjugation of Payloads to Cysteine 34 of Human Albumin Variants. Mol. Pharm. 2015.

39. Schmokel J, Voldum A, Tsakiridou G, Kuhlmann M, Cameron J, Sorensen ES, Wengel J, Howard KA: Site-selective conjugation of an anticoagulant aptamer to recombinant albumins and maintenance of neonatal Fc receptor binding. Nanotechnology 2017, 28:204004.

40. Bukrinski JT, Sonderby P, Antunes F, Andersen B, Schmidt EGW, Peters GHJ, Harris P: Glucagon-like Peptide 1 Conjugated to Recombinant Human Serum Albumin Variants with Modified Neonatal Fc Receptor Binding Properties. Impact on Molecular Structure and Half-Life. Biochemistry 2017, 56:4860-4870.

41. Andersen JT, Dalhus B, Viuff D, Ravn BT, Gunnarsen KS, Plumridge A, Bunting K, Antunes $F$, Williamson $R$, Athwal $S$, et al.: Extending serum half-life of albumin by engineering neonatal Fc receptor (FcRn) binding. J Biol Chem 2014, 289:13492-13502.

42. Jacobs SA, Gibbs AC, Conk M, Yi F, Maguire D, Kane C, O'Neil KT: Fusion to a highly stable consensus albumin binding domain allows for tunable pharmacokinetics. Protein Eng Des Sel 2015, 28:385-393.

43. Andersen JT, Pehrson R, Tolmachev V, Daba MB, Abrahmsen L, Ekblad C: Extending Halflife by Indirect Targeting of the Neonatal Fc Receptor (FcRn) Using a Minimal Albumin Binding Domain. J. Biol. Chem. 2011, 286:5234-5241.

44. Zorzi A, Middendorp SJ, Wilbs J, Deyle K, Heinis C: Acylated heptapeptide binds albumin with high affinity and application as tag furnishes long-acting peptides. Nat Commun 2017, 8:16092.

45. Steiner D, Merz FW, Sonderegger I, Gulotti-Georgieva M, Villemagne D, Phillips DJ, Forrer $\mathrm{P}$, Stumpp MT, Zitt C, Binz HK: Half-life extension using serum albumin-binding DARPin ${ }^{\circledR}$ domains. Protein Engineering, Design and Selection 2017:1-9.

46. Adams R, Griffin L, Compson JE, Jairaj M, Baker T, Ceska T, West S, Zaccheo O, Dave E, Lawson $A D$, et al.: Extending the half-life of a fab fragment through generation of a humanized anti-human serum albumin Fv domain: An investigation into the correlation between affinity and serum half-life. MAbs 2016, 8:1336-1346.

47. Holt $\amalg$, Basran A, Jones K, Chorlton J, Jespers LS, Brewis ND, Tomlinson IM: Anti-serum albumin domain antibodies for extending the half-lives of short lived drugs. Protein Eng Des Sel 2008, 21:283-288.

48. O'Connor-Semmes RL, Lin J, Hodge RJ, Andrews S, Chism J, Choudhury A, Nunez DJ: GSK2374697, a novel albumin-binding domain antibody (AlbudAb), extends systemic exposure of exendin-4: first study in humans--PK/PD and safety. Clin Pharmacol Ther 2014, 96:704-712.

49. Tijink BM, Laeremans $T$, Budde $M$, Stigter-van Walsum $M$, Dreier $T$, de Haard $H J$, Leemans CR, van Dongen GA: Improved tumor targeting of anti-epidermal growth factor 
receptor Nanobodies through albumin binding: taking advantage of modular Nanobody technology. Mol. Cancer Ther. 2008, 7:2288-2297.

50. Andersen JT, Daba MB, Berntzen G, Michaelsen TE, Sandlie I: Cross-species binding analyses of mouse and human neonatal Fc receptor show dramatic differences in immunoglobulin $\mathbf{G}$ and albumin binding. J Biol Chem 2010, 285:4826-4836.

51. Roopenian DC, Low BE, Christianson GJ, Proetzel G, Sproule TJ, Wiles MV: Albumindeficient mouse models for studying metabolism of human albumin and pharmacokinetics of albumin-based drugs. MAbs 2015, 7:344-351.

52. Smith BJ, Popplewell A, Athwal D, Chapman AP, Heywood S, West SM, Carrington B, Nesbitt $A$, Lawson $A D$, Antoniw $P$, et al.: Prolonged in vivo residence times of antibody fragments associated with albumin. Bioconj. Chem. 2001, 12:750-756.

53. Yeh P, Landais D, Lemaitre M, Maury I, Crenne JY, Becquart J, Murry-Brelier A, Boucher $F$, Montay G, Fleer R, et al.: Design of yeast-secreted albumin derivatives for human therapy: biological and antiviral properties of a serum albumin-CD4 genetic conjugate. Proc Natl Acad Sci U S A 1992, 89:1904-1908.

54. Sheffield WP, Marques JA, Bhakta V, Smith IJ: Modulation of clearance of recombinant serum albumin by either glycosylation or truncation. Thromb Res 2000, 99:613-621.

55. Proetzel G, Roopenian DC: Humanized FcRn mouse models for evaluating pharmacokinetics of human IgG antibodies. Methods 2014, 65:148-153.

56. Stein C, Kling L, Proetzel G, Roopenian DC, de Angelis MH, Wolf E, Rathkolb B: Clinical chemistry of human FcRn transgenic mice. Mamm Genome 2012, 23:259-269.

57. Petkova SB, Akilesh S, Sproule TJ, Christianson GJ, Al Khabbaz H, Brown AC, Presta LG, Meng YG, Roopenian DC: Enhanced half-life of genetically engineered human IgG1 antibodies in a humanized FcRn mouse model: potential application in humorally mediated autoimmune disease. Int. Immunol. 2006, 18:1759-1769.

58. Zalevsky J, Chamberlain AK, Horton HM, Karki S, Leung IWL, Sproule TJ, Lazar GA, Roopenian DC, Desjarlais JR: Enhanced antibody half-life improves in vivo activity. Nat. Biotechnol. 2010, 28:157-159.

59. Viuff D, Antunes F, Evans L, Cameron J, Dyrnesli H, Thue Ravn B, Stougaard M, Thiam K, Andersen B, Kjaerulff S, et al.: Generation of a double transgenic humanized neonatal Fc receptor ( $F C R n) / a l b u m i n$ mouse to study the pharmacokinetics of albumin-linked drugs. $J$ Control Release 2016, 223:22-30. 
Special interest papers:

-13. Latvala S, Jacobsen B, Otteneder MB, Herrmann A, Kronenberg S: Distribution of FcRn Across Species and Tissues. J Histochem Cytochem 2017, 65:321-333.

This study mapped the expression of FcRn in 20 tissues across species, and show that the distribution is comparable between human, monkey, rat and mouse, except for within the placenta and in the intestine. The expression pattern in Tg32 mice was similar to that observed for human and monkey.

-14. Pyzik M, Rath T, Kuo TT, Win S, Baker K, Hubbard JJ, Grenha R, Gandhi A, Kramer TD, Mezo AR, et al.: Hepatic FcRn regulates albumin homeostasis and susceptibility to liver injury. Proc Natl Acad Sci U S A 2017, 114:E2862-E2871.

This paper is the first to show FcRn-mediated transcytosis of albumin across polarized epithelial cells in vitro, and reveals a crucial role of liver FcRn in ensuring efficient delivery of newly made albumin to the circulation and maintaining the high serum concentration of albumin.

-39. Schmokel J, Voldum A, Tsakiridou G, Kuhlmann M, Cameron J, Sorensen ES, Wengel J, Howard KA: Site-selective conjugation of an anticoagulant aptamer to recombinant albumins and maintenance of neonatal Fc receptor binding. Nanotechnology 2017, 28:204004.

This study demonstrates that engineered HSA variants with improved FcRn binding affinity may be used to compensate for decreased receptor binding caused by conjugating a drug to C34 of HSA.

-45. Steiner D, Merz FW, Sonderegger I, Gulotti-Georgieva M, Villemagne D, Phillips DJ, Forrer $P$, Stumpp MT, Zitt C, Binz HK: Half-life extension using serum albumin-binding DARPin ${ }^{\circledR}$ domains. Protein Engineering, Design and Selection 2017:1-9.

This study has selected high affinity albumin-binding DARPin domains, and shows that fusion of short-lived molecules to such DARPins result in serum half-lives close to that of endogenous albumin in mice and monkeys, while fusion of two DARPin domains actually extended the half-life beyond that of endogenous albumin.

-51. Roopenian DC, Low BE, Christianson GJ, Proetzel G, Sproule TJ, Wiles MV: Albumindeficient mouse models for studying metabolism of human albumin and pharmacokinetics of albumin-based drugs. MAbs 2015, 7:344-351.

This paper has developed the first mice that lack expression of albumin, in addition to being $\mathrm{hFcRn}$ transgenic. The serum half-life of injected HSA is extended to more than 20 days in such mice, which is comparable to that found in humans.

-59. Viuff D, Antunes F, Evans L, Cameron J, Dyrnesli H, Thue Ravn B, Stougaard M, Thiam K, Andersen $B$, Kjaerulff $S$, et al.: Generation of a double transgenic humanized neonatal Fc receptor ( $F C R n) / a l b u m i n$ mouse to study the pharmacokinetics of albumin-linked drugs. $J$ Control Release 2016, 223:22-30.

This paper describes a novel double hFcRn/HSA transgenic mouse model, and shows that engineerd HSA variants with distinct binding affinity for $\mathrm{hFcRn}$ had correlating serum halflife in the mice. 